\title{
Policy and demographic factors shape deforestation patterns and socio-ecological processes in southwest Ethiopian coffee agroecosystems
}

\author{
Getachew Tadesse*, Erika Zavaleta, Carol Shennan, Margaret FitzSimmons \\ Department of Environmental Studies, University of California at Santa Cruz, 1156 High St., Santa Cruz, CA 95064, USA
}

\section{A R T I C L E I N F O}

\section{Article history:}

Available online

Keywords:

Deforestation

Drivers

Land-use change

Resettlement

Socio-ecological feedbacks

\begin{abstract}
A B S T R A C T
Land-use change, a major driver of biodiversity loss and ecosystem service degradation, is caused by intertwined local and regional forces that shape human-environment interactions. In order to understand the interacting effects of local processes and national policies on landscape changes, we studied two districts of contrasting demographic and land-management histories in southwest Ethiopia. Our main objectives were to understand the extent of forest cover changes through time, and to explore how deforestation rates correlate with (a) local changes in settlement, demographic conditions, and livelihood practices, and (b) broader changes in land-tenure and agricultural development policies in Ethiopia. We found that: (a) over $36 \%$ of the forests were lost since 1973, (b) deforestation rates varied through time due to changes in land-tenure and agricultural development policies, and (c) rates also varied between the two districts with higher rates in Yeki that correlated with demographic pressure from resettlement and agricultural expansion, and lower rates in Decha associated with lower population pressure and in response to forest conservation practices and higher non-timber forest benefits to local communities. The interactions in agricultural policy, land-tenure, demographic dynamics, and conservation policies with forest stability or decline suggested by this study shows the importance of carefully considering the undesirable effects of resettlement and agricultural development policies and the need to support community forest conservation that also benefits local people.
\end{abstract}

(c) 2014 Elsevier Ltd. All rights reserved.

\section{Introduction}

Land-use change is a major threat to biodiversity, ecosystem services, and human well-being in tropical ecosystems (Millennium Assessment, MA 2005). In parts of sub-Saharan Africa where smallscale agriculture remains the major source of rural livelihoods, deforestation remains a primary environmental concern. This is more typical to Ethiopia with over $83 \%$ of the total population living on small-scale agriculture (Central Statistics Agency, CSA 2012). Ethiopia has a long history of intensive agriculture and high population pressure, thus lacking historic data on forest cover and there is no good baseline data about the extent of deforestation rates or forest cover in the past. About $40 \%$ of Ethiopian landmass was arguably covered by forests by the beginning of the 20th $C$. The forest cover has been variably estimated to be decreased from $16 \%$

\footnotetext{
* Corresponding author. Tel.: +1206 48998731 .

E-mail address: gettades@gmail.com (G. Tadesse).
}

in 1950 s, to $2.7 \%$ by 1989 , and to less than $2.2 \%$ recently (Bishaw, 2001; Crummey, 2009; Pankhurst, 1995; Woien, 1995).

Investigations from some parts of Ethiopia suggest that forest cover has increased in the highlands of Tigray, Northern Ethiopia, since 1961 (Meire et al., 2013) including the southern and eastern parts of Tigray region (Teka et al., 2014; Woien, 1995), in Wello in North Ethiopia since the 1930s (Crummey, 1998), and in Chimoga watershed in Northwest Ethiopia (Bewket, 2002). However, most researchers now agree on declining forests in many parts of Ethiopia, and Millennium Assessment (MA, 2005) considered Ethiopia as one of the 29 countries which lost $>90 \%$ of its original forest cover.

The majority high forests in Ethiopia are now limited to the southeastern and southwestern parts of the country. Southwest Ethiopian forests are home to diverse species and ecosystem services including wild coffee, spices, forest honey, and a variety other timber and non-timber forest products on which millions of smallscale farmers depend (Gole, 2003; Senbeta \& Denich, 2006; Tadesse, Zavaleta, Shennan, FitzSimmons, 2014). However, these forests are also under continuous degradation and conversion to 
other agricultural landscapes (Dessie \& Kleman, 2007; Getahun, Rompaeya, Turnhouta, \& Poesen, 2013; Reusing, 2000; Wiersum, 2010).

In many parts of Ethiopia, various drivers of deforestation and land-use changes have been reported such as agricultural expansion (Reid et al., 2000; Tekle \& Hedlund, 2000), logging for construction and fuel (Assefa \& Bork, 2014; Dessie \& Kleman, 2007), increased access to market and major urban centers (Getahun et al., 2013; see also Rudel, 2013), commercial logging and commercial farming (Dessie \& Kleman, 2007), changes in land-tenure and landuse policy, cattle diseases, drought, and resettlement (Reid et al., 2000), and population growth (Bewket, 2002).

It has been shown from other areas that deforestation results from increased local demands (e.g. pressure for more forest products and agricultural land from population growth) that interact with external socioeconomic and policy changes (Lambin, Geist, \& Lepers, 2003). For instance, agricultural expansion by smallholders in tropical regions particularly in sub-Saharan Africa is exacerbated by rural population growth and national polices that promote intensive cereal-based agriculture (Lambin et al., 2003; MA, 2005). In Cameroon, economic recession and subsequent de-urbanization (Mertens, Sunderlin, Ndoye, \& Lambin, 2000; Sunderlin et al., 2000), emerging global markets such as the oil boom, and export prices from coffee and cacoa (Gbetnkom, 2005) have increased deforestation and agricultural expansion. Landscape changes in coffee agroecosystems in Central America have also been reported as being caused by complex and divergent drivers (Schmitt-Harsh, 2013).

Previous studies on land-use changes and deforestation in southwest Ethiopia mostly focused on local drivers of deforestation without examining the broader political and socio-economic processes. In pre-1974 Ethiopia, land-tenure was complex and diverse (Rahmato, 2009) which might have promoted land-tenure security while maintaining customary forest ownership regimes that used to conserve forests. After the national 1974 land-to-the-tiller proclamation, the Derg regime nationalized land and homogenized the pre-existing diverse ownership regimes throughout Ethiopia and allowed local farmers to farm their own plot using usufruct rights (Rahmato, 1994, 2009). This disrupted the preexisting ownership regimes, created land-tenure insecurity, and changed customary forest ownership to state ownership which in turn alienated indigenous people from their forests while causing competition and rivalry for forest resources (Bekele, 2003; Stellmacher, 2007; Wood, 1993). Insecure land-tenure can impact forest cover by reducing tree cover through agricultural expansion and by disrupting customary forest ownership (see Place \& Otsuka, 2001).

The other factor possibly associated with increased deforestation is Ethiopia's agricultural development policy after the 1990s. This policy has promoted intensive farming practices and cropland expansion by providing extension and credit programs to smallscale farmers. In addition to agricultural extension, agricultural investment policies promoted agricultural expansion which may also have encouraged further deforestation and intensification in the region (see Gebreselassie, 2006) as has been reported in many tropical regions (Geist \& Lambin, 2002).

Studies that identify the extent and drivers of deforestation as well as the interaction among drivers will help avoid unintended consequences of policy interventions on the sustainable management of forest resources. The national agricultural development and land-use policies interacting with resettlement programs in southwest Ethiopia could shape demographic and livelihood practices that modify spatial and temporal patterns of deforestation. The degree of resettlement in the region varied from place to place with Yeki district heavily settled with people who came from other parts of Ethiopia than Decha region. Decha region have more indigenous people who more depend on forest products than the people in Yeki (Tadesse, Zavaleta, Shennan, et al., 2014). The contrasting histories of two political districts in the Ethiopian Southwest, Yeki and Decha regions, give us the opportunity to explore how deforestation rates vary in adjacent regions facing comparable political and economic conditions but with key differences in local cultural and livelihood characteristics. We examined how deforestation rates vary between the two districts with contrasting demographic and socio-economic conditions, and how rates correlate with different time periods marked with broader policy and socio-economic changes in Ethiopia and beyond.

\section{Methods}

\section{The study areas}

We studied two major regions of contrasting demographic and land-use histories in southwest Ethiopia: (1) Yeki found at $7.2^{\circ} \mathrm{N}$, $35.3^{\circ} \mathrm{E}$ covering $618 \mathrm{~km}^{2}$ area, and (2) Decha districts (including adjacent forested villages of Gimbo district) found at $36.1^{\circ} \mathrm{E}, 7.1^{\circ} \mathrm{N}$ with a total area of $1392 \mathrm{~km}^{2}$ (Fig. 1A). Rainfall in the region is unimodal with annual precipitation of $>1200 \mathrm{~mm}$ and mean monthly temperature that ranges from $18{ }^{\circ} \mathrm{C}$ to $23{ }^{\circ} \mathrm{C}$ (Ethiopian National Meteorological Services Agency, 2010). Vegetation in the region is predominantly classified as moist Afromontane forests with the surrounding lowland transitional rainforests (Friis, 1992). About 10 of the 58 national forest conservation priority areas of Ethiopia are found in and around these regions.

The major resettlement program in 1984-85 occurred as a national response to the Ethiopian famine crisis (Clay \& Holcomb, 1985; Rahmato, 2003). During this period, the majority of the 600,000 people who came from northern and central parts of Ethiopia were relocated to southwest Ethiopia. Of these about 64,660 people were settled to Kaffa region, including Decha and Gimbo areas; and about 150,939 people to Illubabor region, including Yeki district (Rahmato, 2003). Consequently, indigenous people in Yeki district became less dominant (58.9\%) than they are in Decha and its surrounds (84\%) (CSA, 2011).

Yeki has high population density $\left(\sim 223\right.$ persons $\left./ \mathrm{km}^{2}\right)$ that has doubled since the 1990s (CSA, 2012). Settlers, composed of various socio-cultural groups, practice intensive cultivation than indigenous people. Yeki was dominated by indigenous Majangir and Shako peoples who predominantly practiced shifting cultivation and hunting-gathering before the 1960s (Stauder, 1971). There has been rapid land-use transition from shifting cultivation and hunting-gathering practices to intensive cultivation due to demographic changes, and promotion of cereal cultivation. Resettlement and villagization programs have promoted sedentary agriculture while discouraging hunting-gathering and shifting cultivation practices.

The people of Decha are predominantly indigenous Kaffichos (81\%) who practice subsistence cereal cultivation mixed with forest coffee and various non-timber forest products. Settler population in this district and its surrounds is $<11 \%$ (CSA, 2012). Average population density of Decha and surrounding region is $\sim 86$ persons $/ \mathrm{km}^{2}$ with an increase from 54 to 86 persons $/ \mathrm{km}^{2}$ between 1990 s and 2010 (CSA, 2012; Center for International Earth Science Network, CISEN 2012). Minority Manjos belong to the Kafficho ethnic groups who used to practice hunting and gathering before 1980s and who are now practicing intensive cereal cultivation (Yosinda, 2009). Indigenous peoples in Decha district have a long history of sedentary cultivation practices with high use of non-timber forest products. The predominant coffee production in Yeki district is 

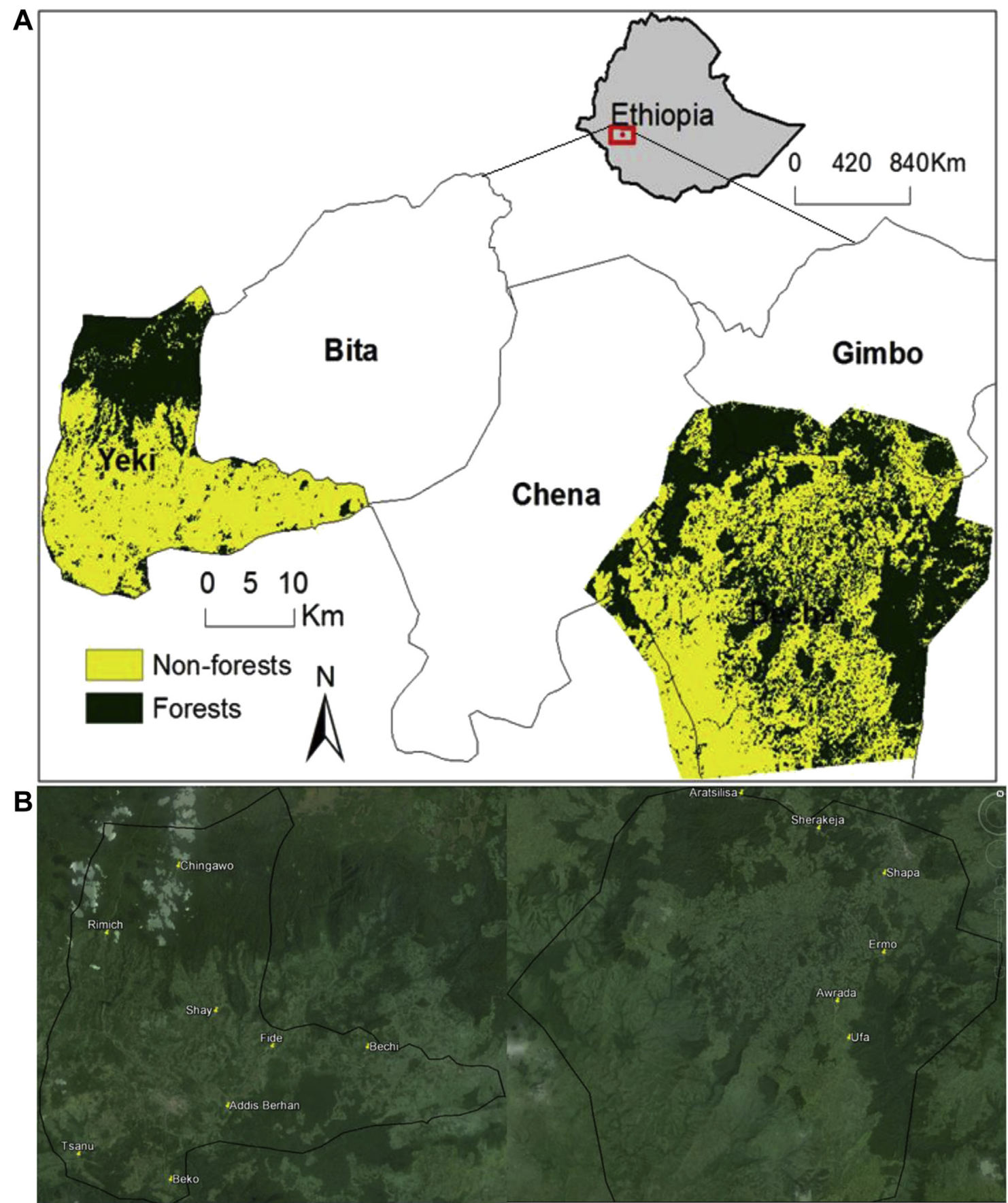

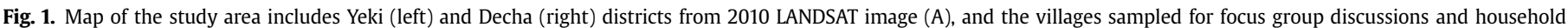
surveys overlayed on Google Earth 2014 image (B) (G. Tadesse).

garden and plantation coffee systems while it is semi-forest and wild coffee in Decha.

In addition to variation in the degree of using non-timber forest products (NTFPs), Yeki and Decha also vary in the extent and approach of forest conservation. Since late 1990s, Participatory Forest Management (PFM), a community-based forest management program, have been introduced to many regions in Ethiopia, including Decha district. PFM aims to involve local people in management and decision-making for food security and poverty alleviation through sustainable utilization of forest resources (Winberg, 2010). Although there have been effective local institutions for managing forest resources supported by PFM schemes in Decha, such approaches have not been actively introduced to Yeki. Therefore we examined whether the variations in conservation approaches between the two districts were reflected on the variations in their corresponding rates of forest cover changes.

Data collection, image processing, and change detection

We acquired LANDSAT images of 1973, 1987, 1995, 2001, and 2010 of the region from USGS (http://glovis.usgs.gov/). We geoprocessed the images, and made geeometric and radiometric corrections. We used the 1973 image to compare the extent of forest cover of subsequent years relative to the 1973 forest cover. This is because no earlier images were available and we could not know 
the pre-1973 extent of forests in a region that has essentially always been inhabited. The year 1973 also precedes the major changes in land-tenure and land re-distribution scheme in Ethiopia that induced much of the subsequent landscape changes. Later images were from 1987 coincided with major resettlement in the region; from 1995 following changes in agricultural land policy and investment after 1991; from 2001 coincided with the introduction of forest conservation activities; and finally from the most recent land-cover data available from LANDSAT at the time of this study (2010) (Table 1). For the spatio-temporal analysis of change detection, all of the images acquired were from dry seasons, between December and February (Table 1) with minimum cloud cover $(<10 \%)$, less atmospheric haze, and less moisture content.

Our major steps for image classification and change detection were (1) collecting training samples (by reviewing ground-truth data collected in 2009 and 10, SPOT 5 m-resolution image from 2007, and recent Google Earth images) for classification (2) generating signature files, (3) executing supervised, maximum likelihood classification tool, and (4) post-classification processing. For image classification, we used ERDAS Imagine 9.2 and a toolbar introduced at ArcGIS 10 with spatial analyst and image analysis extensions. The ground-truthing data were based on the 362 ground control points sampled from the different land-covers including forests of varying degradation levels, coffee agroforests, croplands, roads, settlements, and rivers/water bodies. The features that were classified and interpreted were (a) roads/settlements, (b) agricultural areas/ croplands, (c) grazing lands/pastures, (d) coffee/tea/Eucalyptus plantations, and (e) coffee agroforests (collectively categorized as non-forests for simplicity purposes), and (f) natural forests. Specific areas of change and change rate were calculated for the change detection analysis, along with spatial distribution of changed types and accuracy assessment using overall classification accuracy index.

We considered the FAO definition of forests as areas with $>0.5$ ha covered by trees of $5 \mathrm{~m}$ height or more, and with a canopy cover of $>10 \mathrm{~m}$. All other land-uses that were not covered by natural forests were considered as non-forests. All degraded forests were considered as forests since we sampled forests of different degradation levels and we had adequate information about most forest fragments in the study area. We used testing samples to evaluate the accuracy of the final classification using accuracy assessment. We classified the images using the training samples that characterize distinct sample areas in land-use types. Elevation and slope data for each land-cover zones

\section{Table 1}

Socio-ecological dynamics of the region (1973-2010) based on data from local information and literature survey with the dates of satellite images acquired for Yeki and Decha.

\begin{tabular}{|c|c|c|c|}
\hline Year & Trends and events & $\begin{array}{l}\text { Satellite } \\
\text { data }\end{array}$ & Source \\
\hline $1970 \mathrm{~s}$ & $\begin{array}{l}\text { Major land redistribution (1974), majority } \\
\text { of households given entitlements to } \\
\text { cultivated lands }\end{array}$ & $2 / 2 / 1973$ & MSS \\
\hline $1980 s$ & $\begin{array}{l}\text { Large-scale resettlement ( } 1984 / 5) \text {, increase } \\
\text { in oxen plowing, decrease in fallowing, } \\
\text { missionaries and introduction of exotic } \\
\text { species and fruits, large state farms ( } 1987) \text {, } \\
\text { coffee, tea and Eucalyptus plantations ( } 1980 \\
-1989 \text { ) }\end{array}$ & $22 / 1 / 1987$ & MSS \\
\hline $1990 \mathrm{~s}$ & $\begin{array}{l}\text { Promotion of cereal based production, } \\
\text { extension and credit programs, agricultural } \\
\text { investment policy, Ethiopian Forestry } \\
\text { Action Plan (1994) }\end{array}$ & $17 / 3 / 1995$ & TM \\
\hline $2000 s$ & $\begin{array}{l}\text { Market-based agricultural investment, } \\
\text { large-scale agricultural expansion, } \\
\text { Participatory Forest Management (PFM), } \\
\text { designation of National Forest Priority Areas } \\
\text { (NFPA), UNESCO Biosphere Reserve }\end{array}$ & $\begin{array}{l}5 / 2 / 2001 \\
3 / 1 / 2010\end{array}$ & $\begin{array}{l}\text { TM } \\
\text { ETM+ }\end{array}$ \\
\hline
\end{tabular}

were calculated using 90-m resolution Shuttle Radar Topography Mission layers in ArcMAP 10. We obtained population density data between 1990 and 2010 from the database in Center for International Earth Science Information Network, CIESIN (2012). Here we projected and filled back the population densities of 1990, 2000, and 2005 for the two districts based on the conversion factor derived from the ratio of national data on the population density of 2010. We multiplied this ratio by the corresponding population density values available from CIESN (2012) for the corresponding years in 1990, 2005, and 2000.

\section{Focus group discussions}

To obtain first-hand information about local landscape changes and to understand the various drivers of deforestation and associated local socio-ecological feedbacks, we carried out focus group discussions and household interviews between July 2009 and December 2010. We convened ten focus group discussions (FGD) composed of 8-14 people from eleven peasant associations ( 7 from Yeki and 4 from Decha) from areas representing varying levels of forest cover (Fig. 1B). The focus group discussion was about the extent of major landscape changes and their drivers (and associated coping strategies) that occurred during the Derg regime (1974-1991), and the current Ethiopian government (1991-2010). Each focus group discussion was carried out both by field assistants and the corresponding author, and all participants were encouraged to share their own perspectives sometimes by isolating individual participants to reduce the effects of groupthink. Even though there is an inevitable element of observer bias in focus group discussions, we made sure to build a discussion environment where there was an active exchange of ideas between ourselves and participants.

\section{Household surveys}

We used the result from the focus group discussions to specify a more in-depth questionnaire for the household surveys. Each interview was made by the corresponding author and field assistants through a semi-structured questionnaire in the homestead of the informant. A total of 105 household interviews were made from different socio-cultural groups in the ten villages, and respondents were randomly selected heads of households. These surveys were used to identify the different drivers of deforestation at local levels and how each household responded to any changes in forest cover and agricultural lands.

During the interviews, we encountered many challenges including some respondents being less honest about deforestation and landcover changes fearing retaliation by officials for disclosing negative aspects of forest conservation, or anticipating that our documentation about forest cover declines would bring about policy changes that can directly affect their livelihoods. Other challenges included the reliability of recall data when it comes to precise periods and hence we used political regimes as references in addition to using approximate time periods. We cross-checked the information from the focus groups and household informants for the same area in order to avoid the tendency of people idealizing the past or viewing the past through "rose-colored glasses". To increase the validity of our survey findings, we triangulated the data from several data sources including groundtruthing observations, literature reviews, and discussions with local officials.

\section{Data analyses}

We determined annual deforestation rates using a standardized index. 
$P=\frac{100}{t_{2}-t_{1}} \ln \frac{A_{2}}{A_{1}}$

where $P$ is annual percentage of forest loss, and $A_{1}$ and $A_{2}$ are the amount of forest cover at time $t_{1}$ and $t_{2}$ respectively (Puyravaud, 2003). In order to evaluate the accuracy of the final maps, post classification accuracy assessment for the major land-cover classes was calculated based on overall, user's and producer's accuracy (Congalton, 1991).

Using zonal statistics in the Arctool box, we calculated the mean population density of people living inside and outside forested areas to examine whether deforestation patterns were associated with demographic factors in the landscape and compared using chi-square tests. In order to compare deforestation rates between the two districts with respect to the effects of resettlement and forest conservation on forest cover, we used before-after-control-impact (BACI) observational experiment with the resettlement on Yeki that included forest loss rates between 1973 and 1995; and PFM on Decha that included forest loss rates between 1996 and 2010. We used ANOVA, and nonparametric chi-square tests to examine significant variations between the two regions in the effects resettlement and management have on forest loss rates. We then compared for any effects of elevation range, slope, and roads on deforestation patterns using chi-square tests.

\section{Results}

Forest cover changes in southwestern Ethiopia

The overall mean land-cover accuracy assessment index was $79.8 \%$ with classification accuracy of the thematic classes that varied from 74.2 to $83.3 \%$ (1973-2010) with mean Kappa coefficient (Khat $=0.8$ ) (Table 2 ). Total forest cover declined from $62 \%$ to $41 \%$ of the total landscape in 2010 . Our study shows that between 1973 and 2010, forest cover have declined by 36\%. In the two study areas combined, only 64\% of the 1973 forest cover remained by 2010. Consequently, the overall (Yeki and Decha) landscape changed from forest-dominated (58\% forests) to nonforest dominated landscapes (37\% forests) during the last four

Table 2

Landscape and forest cover changes in the study region, and Yeki and Decha regions (1973-2010), 1973 image was used as reference data.

\begin{tabular}{llllll}
\hline LULC (ha) & Year & & & & \\
\cline { 2 - 6 } & 1973 & 1987 & 1995 & 2001 & 2010 \\
\hline LULC in Yeki district & & & & & \\
Forests (ha) & 40,981 & 26,579 & 22,504 & 21,392 & 19,973 \\
Cultivated lands (ha) & 11,012 & 13,399 & 19,621 & 19,387 & 18,531 \\
Coffee agroforests (ha) & 9769 & 21,784 & 19,638 & 20,984 & 23,259 \\
\% 1973 forest remaining & & 64.9 & 54.9 & 52.2 & 48.7 \\
Annual forest loss (ha) & & 1029 & 509 & 185 & 158 \\
Annual \% forest loss (P) & & 5.4 & 1.2 & 0.9 & 0.8 \\
LULC in Decha district & & & & & \\
Forests (ha) & 76,491 & 67,079 & 63,817 & 56,809 & 54,834 \\
Non-forests (ha) & 62,668 & 72,080 & 75,342 & 82,350 & 84,325 \\
\% 1973 forest remaining & & 87.7 & 83.4 & 74.3 & 71.7 \\
Annual forest loss (ha) & & 672 & 408 & 1168 & 219 \\
Annual \% forest loss (P) & & 1.6 & 0.4 & 1.9 & 0.4 \\
Yeki + Decha & & & & & \\
Forest cover & 117,472 & 93,658 & 86,321 & 78,201 & 74,807 \\
Non-forests & 83,449 & 107,263 & 114,601 & 122,721 & 126,115 \\
\% 1973 forest remaining & & 0.79 & 0.73 & 0.665 & 0.636 \\
Annual forest loss (ha) & & -1701 & -917.13 & -1353.3 & -377.11 \\
Annual forest loss (P) & & -1.6182 & -1.0197 & -1.6465 & -0.493 \\
Accuracy assessment (\%) & 78.5 & 83.3 & 74.2 & 83 & 80 \\
\hline
\end{tabular}

decades (Table 2). Annual deforestation rates were highest between 1973 and 1995 ( $P=3.0 \%$ ), and from 1995 to 2001 $(P=2.5 \%)$. Deforestation rates have decelerated in both study regions since 2001 .

Effects of elevation, distance from roads, and population on deforestation patterns

Forest remnants in the study region were found from low to high elevations ranging from $826 \mathrm{~m}$ to $2531 \mathrm{~m}$ (Table 3). There was no significant variation in mean elevation distribution between the remaining forests and non-forest land-use types $\left(F_{1,8}=3.1\right.$, $\left.p=0.12 ; \chi^{2}=2.9, p=0.09\right)$. However, most of the forests $(74 \%)$ were found between 1500 and 2000 m elevations where $50 \%$ of the total area of the landscape was found (Table 3). Larger fragments were found in higher elevations and the size of forest fragments increased with increase in elevation $(p=0.047)$. Elevation was also associated with patterns of deforestation in both Yeki $\left(\chi^{2}=40.1\right.$, $\mathrm{df}=3, p<0.001)$ and in Decha districts $\left(\chi^{2}=9.3, \mathrm{df}=3, p=0.026\right)$. Slope was also associated with deforestation rates in both Yeki $\left(\chi^{2}=24.1, \mathrm{df}=3, p<0.001\right)$ and Decha $\left(\chi^{2}=109, \mathrm{df}=3, p<0.001\right)$. Generally, forests in Decha occurred in more steep-slopes (mean $14^{\circ} \pm 6$ ) of wider slope ranges (range $48^{\circ}$ ) than in Yeki (mean $6^{\circ} \pm 5$, range $40^{\circ}$ ). Forest cover percentages increased away from roads $\left(\chi^{2}=4.4, p=0.04\right)$. The percentage of forest cover within $5 \mathrm{~km}$ of major roads was $30 \%$ of the total landscape but it decreased to $17.7 \%$ within $1 \mathrm{~km}$ from major roads.

\section{Spatial variation in deforestation rates and patterns}

We found that the rates and patterns of forest cover declines between the two regions were different (see Fig. 2). Over the last 37 years, mean deforestation rate in Yeki $(P=2.1 \%)$ was higher than in Decha $(P=1.1 \%)$. Only $48.7 \%$ of Yeki forests that existed in 1973 remained by 2010 compared to the $71.7 \%$ remaining in Decha over the same period (Table 2). During this period, Yeki landscapes have been changed from forest-dominated (66\% forest cover) to nonforest-dominated ( $32 \%$ forest cover). On the other hand, the overall forest cover in Decha landscape decreased from 55\% to 39\% from 1973 to 2010 (Table 2).

Based on our BACI analysis, forest loss was higher in Yeki (more resettlement as the treatment) after 1984 resettlement (see slope in Fig. 3) than during the same period in Decha (less resettlement as control; $\chi^{2}=16.3, p<0.001$ ). Between 2001 and 2010, deforestation rates in Yeki district (without PFM, control) was higher than Decha district (with effective PFM program, treatment) $\left(\chi^{2}=10.1\right.$, $p<0.001$ ) (Fig. 3).

We found significant variations in the patterns of population growth and density between forested and non-forested areas in the two districts $\left(\chi^{2}=5.4, p=0.02\right.$ ) (Table 4). Population density of Yeki was generally higher (223 persons $/ \mathrm{km}^{2}$ ) than Decha (79 persons $/ \mathrm{km}^{2}$ ). The density of population living inside forests of Yeki were lower than the density of people living outside forested areas

Table 3

Relative dominance of forests and deforestation patterns along altitudinal gradients.

\begin{tabular}{lcccccc}
\hline $\begin{array}{l}\text { Elevation } \\
\text { range }(\mathrm{m})\end{array}$ & \multicolumn{2}{l}{$\begin{array}{l}\text { \% Forest cover in } \\
\text { total landscape }\end{array}$} & & \multicolumn{2}{l}{$\begin{array}{l}\text { \% of total } 2010 \\
\text { forest cover }\end{array}$} & \multirow{2}{*}{$\begin{array}{l}\text { \% Forest loss } \\
1973-2010\end{array}$} \\
\cline { 2 - 3 } & 1973 & 2010 & & 1973 & 2010 & \\
\hline $500-1000$ & 0.6 & 0.2 & & 0.7 & 0.2 & 12.8 \\
$1001-1500$ & 41.4 & 6.1 & & 41.2 & 18.8 & 20.4 \\
$1501-2000$ & 28.8 & 23.6 & & 51.4 & 74 & 64.4 \\
$2001-2500$ & 0.58 & 2.4 & & 6.7 & 7.1 & 47.6 \\
All landscape & 71.3 & 32.3 & & 100.0 & 100 & 44.7 \\
\hline
\end{tabular}




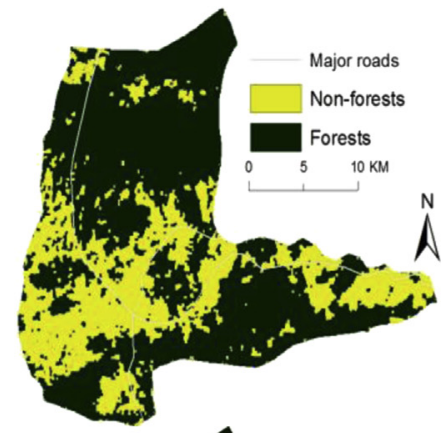

1973

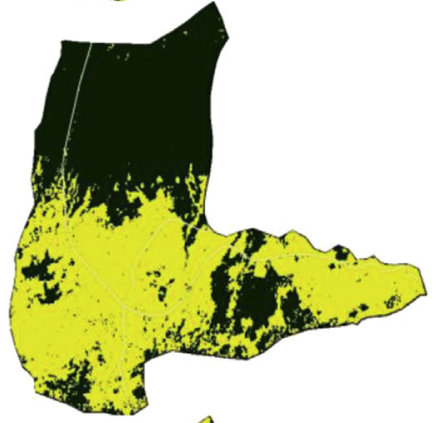

1987

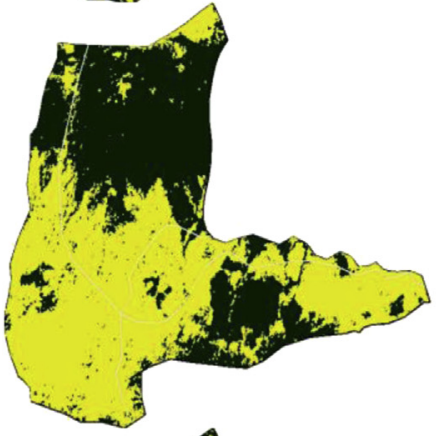

1995

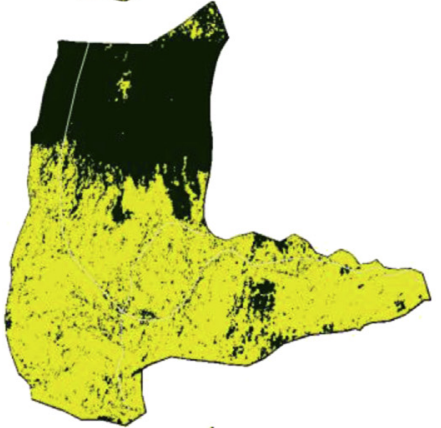

2001
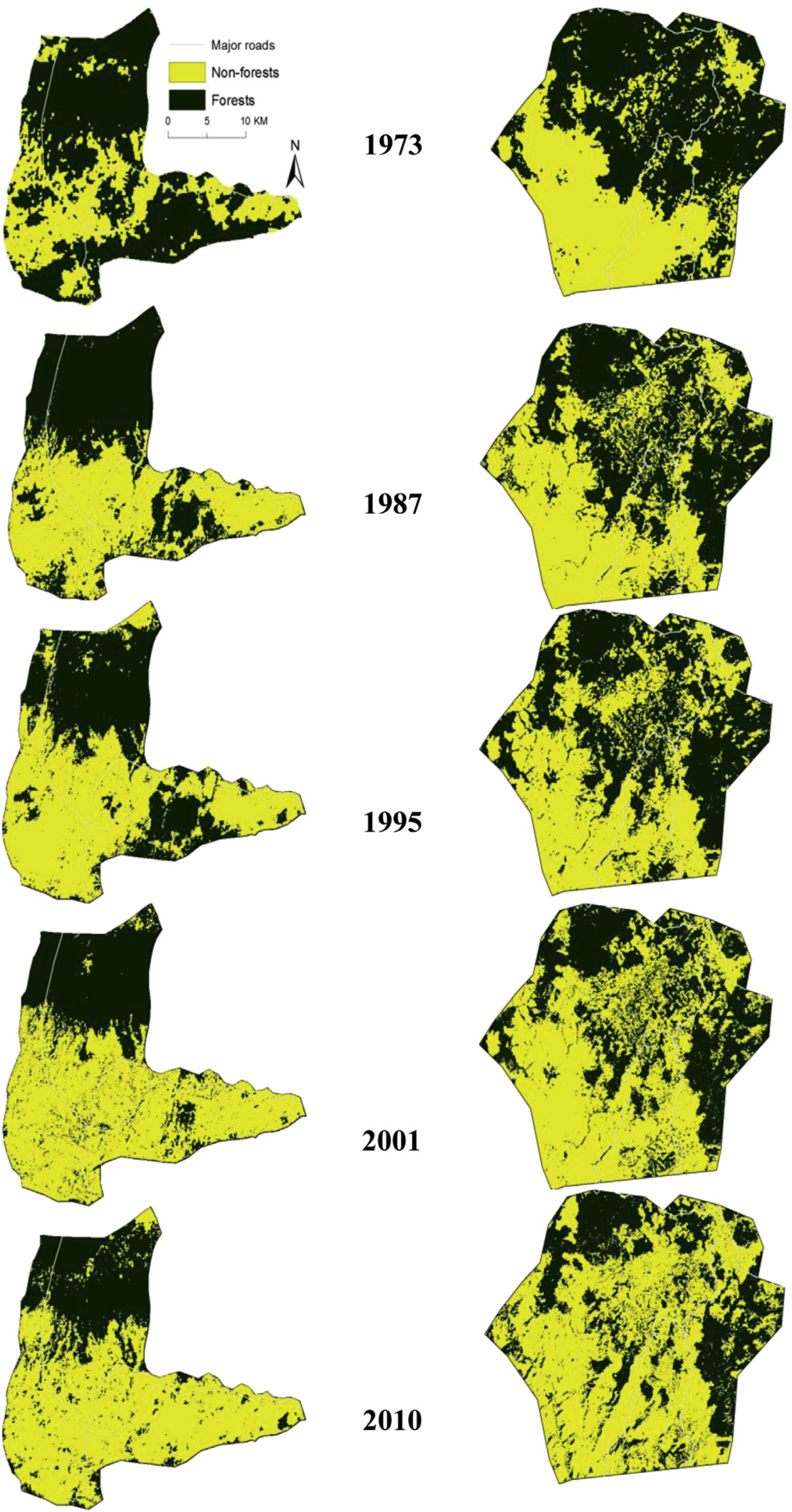

Fig. 2. Forest cover change detection maps from 1973 to 2010 of Yeki district (left column) and Decha region (right column) (G. Tadesse).

(settlement, croplands and coffee farms) (Table 4). In contrast, the density of population living inside forests in Decha was higher than outside forested areas. In Yeki, forested areas had lower increase in population density $\left(+111\right.$ persons $\left./ \mathrm{km}^{2}\right)$ compared to non-forested areas $\left(+127\right.$ persons $\left./ \mathrm{km}^{2}\right)$ between 1990 and 2010. Meanwhile, in Decha, the increase in population density of forested regions $(+42$ persons $\left./ \mathrm{km}^{2}\right)$ was higher than that outside forested regions $(+22$ persons $/ \mathrm{km}^{2}$ ). 


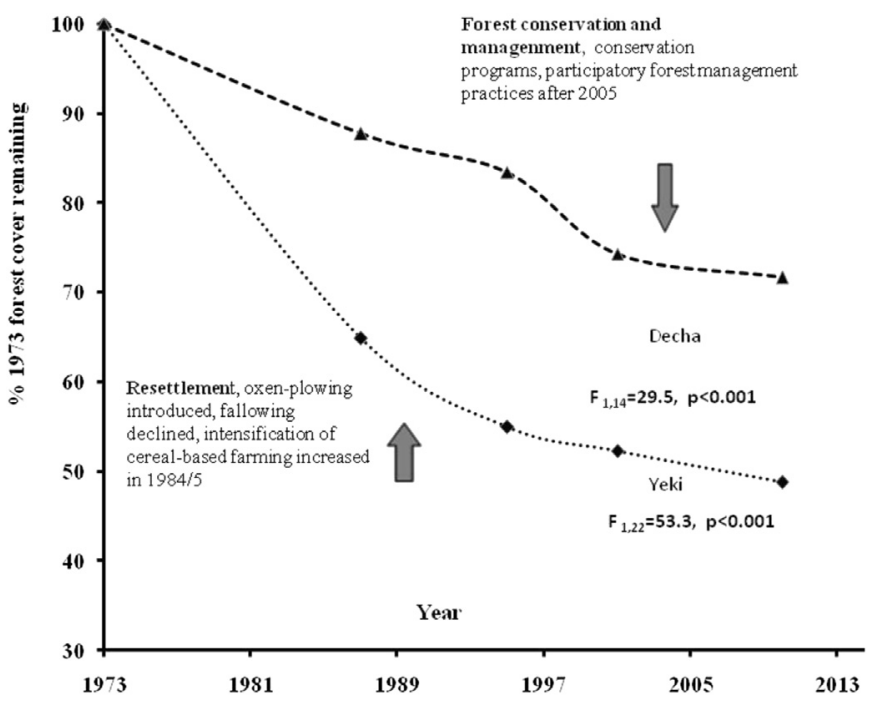

Fig. 3. Deforestation trends in Yeki and Decha districts based on interpolated slopes between observed dates. BACI analysis shows temporal trends are consistent with the hypotheses that resettlement in Yeki (1984/5) and forest protection (2005) in Decha influenced forest loss rates relative to the district that did not experience each policy (G. Tadesse).

\section{Local perceptions of deforestation and land-use changes}

The majority of interviewed households (95\%) reported that, during the last four decades they had observed a decrease in forests and grazing lands, and an increase in coffee farms and plantations (Figs. 4 and 5). Only 5\% of the respondents stated that forests and grazing lands had expanded during the same period. Over $89 \%$ of households described a significant decrease or absence of fallowing between 1980s and 1990s, which they attributed to rapid land-use conversion and shortage of farmland associated with population growth. According to local informants, fallowing of land has been discouraged by local officials since it was considered as wasteful, and individuals who practiced fallowing were identified as having spare land that should be redistributed to other households. Informants also reported that the period of rapid deforestation overlapped with the period when settlers came to the region, and when intensive production and oxen plowing became more common.

Respondents reported that the largest expansion of cultivated fields and settlements occurred after the (1) 1974 land-tenure changes, (2) 1984/5 major resettlement that followed rapid agricultural expansion, and (3) 1991 regime change that followed local land grab, and land redistribution. This was also confirmed by our findings from the geospatial data and remote sensing analysis.

\section{Deforestation drivers and feedbacks in Yeki and Decha}

In both regions, most of the forest cover loss since 1980s was accompanied by a decline in grazing lands by $30 \%$, an expansion of

Table 4

Population density of forested and non-forested areas from 1990 to 2010 in Yeki and Decha.

\begin{tabular}{llllll}
\hline \multirow{2}{*}{ Year } & Yeki & & Decha & \\
\cline { 2 - 3 } \cline { 5 - 6 } & Non-forests & Forests & & Non-forests & Forests \\
\hline 1990 & 144 & 125 & 52 & 56 \\
2000 & 190 & 188 & 43 & 52 \\
2005 & 242 & 210 & 65 & 73 \\
2010 & 271 & 236 & 73 & 98 \\
\hline
\end{tabular}

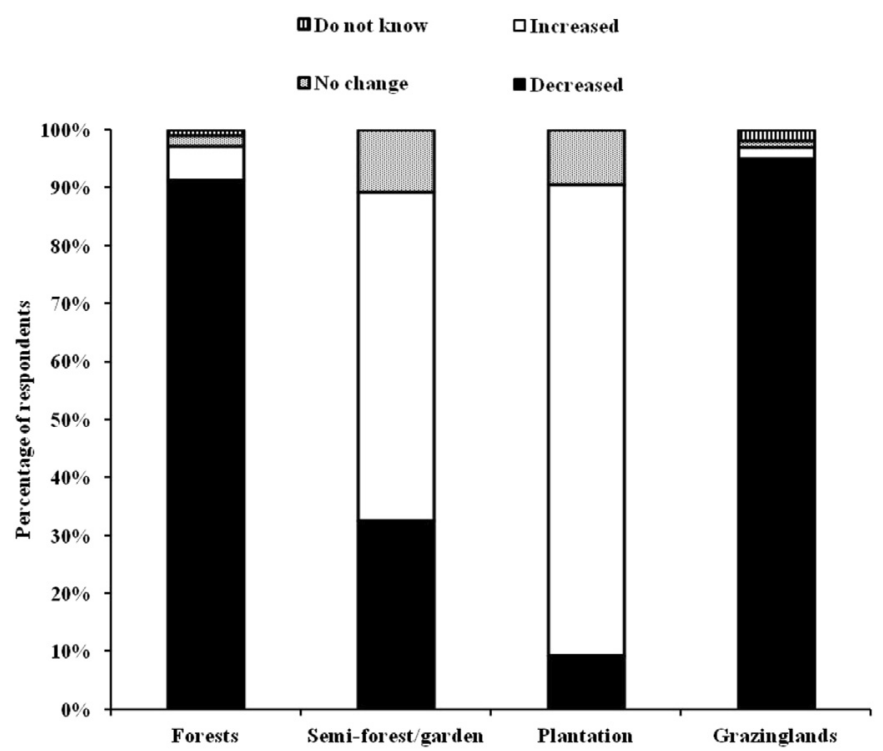

Fig. 4. Changes in major land-use units based on interviews about local perceptions (plantation refers mainly to Eucalyptus) (G. Tadesse)

(a) cultivated lands by $140 \%$, (b) smallholder coffee farms by $265 \%$, (c) coffee plantations by $2250 \%$, and (d) tea and eucalyptus plantations by $1200 \%$ and $1300 \%$ respectively. The majority of the household representatives interviewed $(87 \%)$ reported that they grow coffee while only $2 \%$ reported that they grow tea. According to the informants, over $55 \%$ of the changes (increase or decrease) in the size of coffee farms owned by households were due to conversions from forests (and crop fields) to coffee farms, or conversion of coffee to other croplands. About $18 \%$ and $27 \%$ of respondents ascribed changes in coffee farm size, respectively, to market drivers, and external demographic/policy drivers.

Over half of the informants reported that they responded to the loss of forests and forest resources in the region either by planting fast growing trees, or by using non-forested land such as coffee farms and annual crop fields as sources for forest-based goods. Informants reported that Eucalyptus plantations have proliferated in the region mainly during the last 10 years. About $57 \%$ of respondents reported that they have an average of 0.1 ha of Eucalyptus, an equivalent of 350 individuals planted per household over the last 10 years. Overall, about $90 \%$ of all households surveyed indicated that they had one or more of the three types of plantations (tea, coffee, or Eucalyptus) on their land.

Focus group discussions from the 10 villages in both districts reported 16 proximate and underlying drivers of deforestation that were not mutually exclusive categories (Table 5). The most commonly reported drivers in Yeki were agricultural expansion, population growth, formal resettlement, coffee expansion and villagization. Agricultural expansion, land-tenure changes, charcoal and fuel-wood harvesting, population growth, investment and plantations, and formal resettlement were the most reported drivers in Decha region. Grazing land expansion, climate change, and conflict were also among the major drivers stated by local people.

\section{Discussion}

Does forest cover loss occur in southwest Ethiopia?

We found that landscape changes in southwest Ethiopia have been rapid over the last 37 years. These changes included 


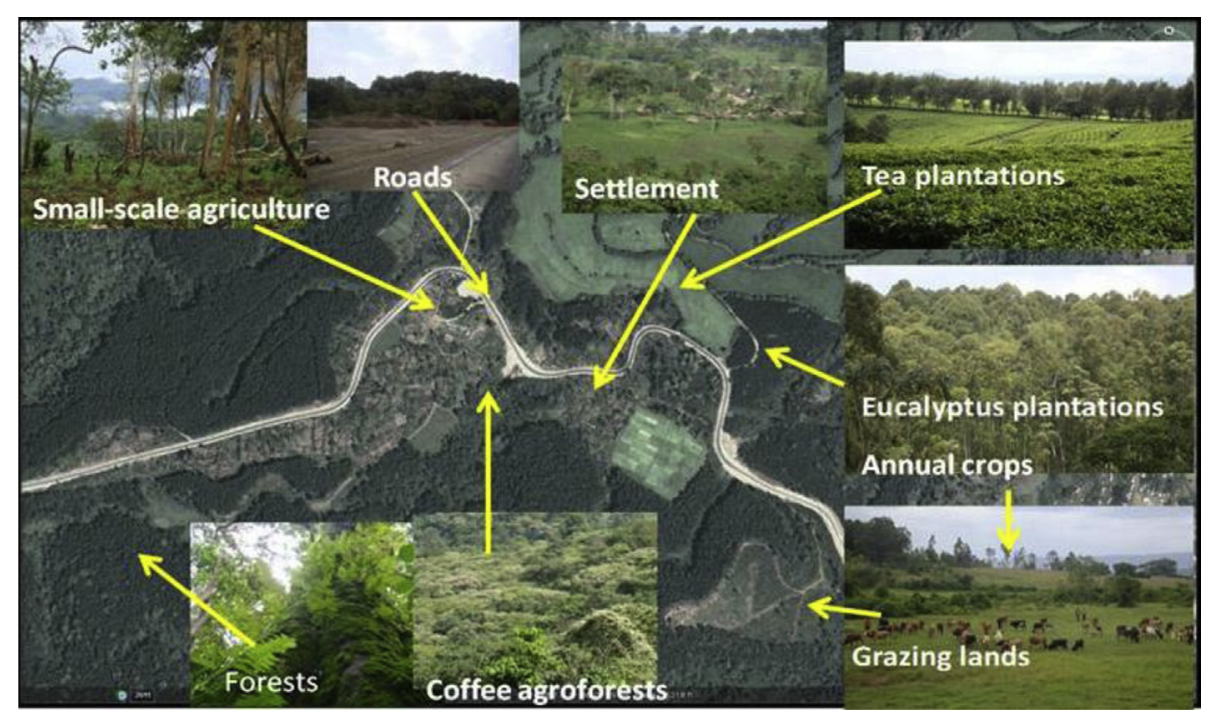

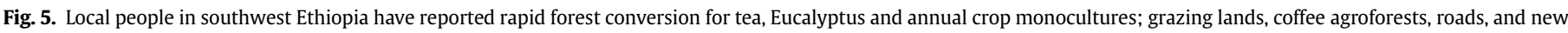
settlements ( $\mathrm{G}$. Tadesse).

expansion of agricultural areas (including coffee farms, tea and Eucalyptus plantations, and small-scale cultivated lands) and decline of forest cover. Generally, the extent and patterns of deforestation depended on type of cultivation pursued, distance from roads and population density centers and elevation. Topography and elevational gradients also affected deforestation patterns. Many forest fragments occurred at higher elevations (in hill-slopes) that are less suitable for cultivation although some smaller fragments still persisted in lower elevations. If forest loss spreads to higher elevations, it will have detrimental effect to biodiversity known for high endemism at higher altitudes (see Hall, Burgess, Lovett, Mbilinyi, \& Gereau, 2009). Deforestation patterns were also affected by slope gradients with a general decrease in forest loss as the steepness of slope increases. This was possibly due to lower rates of forest conversion to agricultural lands at very steep-slopes.

As we sampled regions from $5 \mathrm{~km}$ to $1 \mathrm{~km}$ buffer distances within major roads forest cover decreased by half. These patterns were consistent with high rates of deforestation observed in 1980s when most roads in the region were expanded. Roads are associated with deforestation since they provide access to human disturbance, logging, and overexploitation by increasing proximity to markets (Laurance et al., 2001) and population pressure

Table 5

Percentage distribution of deforestation drivers as reported by focus group participants in Yeki and Decha districts.

\begin{tabular}{lcc}
\hline Drivers & \% Reported Yeki & \% Reported Decha \\
\hline Agricultural expansion & 100 & 100 \\
Coffee expansion & 86 & 25 \\
Charcoal/fuel-wood & 57 & 100 \\
Climate change & 29 & 0 \\
Conflict & 43 & 0 \\
Formal resettlement & 86 & 25 \\
Grazing & 14 & 25 \\
Illegal resettlement & 43 & 25 \\
Infrastructure/roads & 71 & 25 \\
Investment/plantations & 64 & 75 \\
Land-tenure change & 71 & 100 \\
Logging & 71 & 25 \\
Population growth & 100 & 75 \\
Villagization & 86 & 0 \\
\hline
\end{tabular}

(Trombulak and Frissell, 2000). With expansion of more roads in the future, deforestation will continue to increase in all forested areas including smaller-remnants at lower elevations and to inaccessible-slopes at higher elevations. Laurance and Balmford (2013) argued that more than 95\% of Amazonian deforestation occurs within $50 \mathrm{~km}$ of a road and that keeping roads out of natural habitats is the most effective approach to protect natural ecosystems.

These rapid land-use changes and deforestation caused a substantial loss of diverse Afromontane forest remnants that support high biodiversity and ecosystem services (Senbeta \& Denich, 2006; Tadesse, Zavaleta, Shennan, 2014a; Tadesse, Zavaleta, Shennan, et al., 2014a). Unlike Afromontane forests of the Bale Mountains in south Ethiopia, which remained relatively stable between 1973 and 2008 (Kidane, Stahlmann, \& Beierkuhnlein, 2012), forest cover in southwest Ethiopia notably decreased. Deforestation trends in our study region was consistent with other estimates for natural high forests of Ethiopia from 1973 to 1990 (Reusing, 2000), including dry Afro-montane forests in the central plateau of Ethiopia (between 1982 and 1994, Melaku, 2003), central and southern Rift Valley woodland vegetation (between 1973 and 2006, Garedew, Sandewall, Soderberg, \& Campbell, 2009), and dry Afromontane vegetation in other regions of Ethiopia (Tekle \& Hedlund, 2000; Zeleke \& Hurni, 2001). Forest loss in Yeki and Decha between 2001 and 2010 (1975 ha; 1419 ha respectively) were also comparable to the forest loss rates from the global data estimated by Hansen et al. (2013) between 2000 and 2012 extracted from the two districts (1481 ha; 1088 ha). Similar trends of deforestation occurred in sub-Saharan Africa between 1975 and 2000 with 57\% expansion of agricultural lands and 16\% decline in forest cover (Brink \& Eva, 2009). The trends of deceleration of deforestation rates since 2001, observed in both Decha and Yeki through this study, are similar to what has been observed in other regions in Ethiopia and Africa (FAO, 2009).

Do local variations in deforestation rates correlate with local and national drivers?

We found strong observed differences between the two study districts in terms of (a) forest loss rates, (b) patterns of human-forest interactions that influenced deforestation rates, and (c) 
informant-reported deforestation drivers. The patterns of deforestation varied between the two districts where large-scale forest loss was observed in Yeki similar to frontier cultivation for large-scale coffee plantations. In contrast, deforestation pattern in Decha has been patchy due to small-scale cultivation (Fig. 2). Within Yeki, we observed that forest cover was more extended in areas where topography is not favorable for agricultural expansion or investment and these areas also correlated with areas where there was a high representation of indigenous people. Deforestation rates varied between the two districts with higher rates in Yeki correlated with (1) demographic pressure from higher resettlement and agricultural expansion, and (2) lower rates in Decha associated with lower population pressure and in response to forest conservation practices associated with non-timber forest benefits to local communities.

\section{Resettlement and agricultural expansion}

The highest deforestation period in Yeki overlapped with largescale resettlement that increased demographic pressure, investment, and competition for land and forest resources. Although the resettlement program of the 1984-85 was intended to promote food security and to reduce population pressure of vulnerable areas, it brought increased pressure on the settled landscapes that resulted in undesirable consequences of deforestation (Rahmato, 2003) as has been reported in other forested regions (see Peres \& Schneider, 2012).

According to local informants, supported by our own observations and literature analysis on resettlement and agricultural policy, resettlement that was not carefully planned along with demographic pressure, and villagization contributed to conflict and forest degradation in the region (see Vaughan, 2003; Woube, 2005). Additionally, land rents increased with more settlers coming to Yeki district forcing native people to sell their land and to clear more forests. Some temporary contract workers in state and individual coffee farms also caused deforestation through illegally settling and harvesting fuel-wood and charcoal and clearing forests for small-scale agriculture (Tepi Coffee Plantation Enterprise, TCPE 2010; Tadesse, Zavaleta, Shennan, 2014a,b; Tadesse, Zavaleta, Shennan, et al., 2014c). The absence of non-farm incomes for migrant laborers in towns and around state-owned plantations in the study areas contributed to continued exploitation of the forests through fuelwood selling and charcoal production (see Rudel, 2013). In this sense, resettlement may also have created indirect opportunities for further forest loss through the effects of increased agricultural enterprise on temporary labor opportunities in Yeki district. The negative effects of resettlement on woody vegetation cover has also been reported by Elliott, Burnside, Broomhead, Kinsey, and Kwesha (2006) in Zimbabwe. In the region both small-scale and large-scale agricultural expansion is rapidly occurring. Large-scale investments on coffee (17,100 ha, TCPE 2010), tea ( $>2580$ ha), Eucalyptus ( $>1300$ ha) plantations occurred after the 1980s. Such land-use conversions are widespread at national scales, where Ethiopian government leased at least 435,287 ha of land for large-scale monoculture farms mostly in the south and southwest parts of the country (Ministry of Agriculture, MoARD 2012).

\section{Participatory forest conservation}

The lower deforestation rates of Decha compared to Yeki appears to be explained by better forest protection from indigenous forest-based livelihoods (see Hylander, Nemomissa, Delrue, \& Enkossa, 2013), recent PFM schemes which contributed to deceleration in deforestation rates of Decha in 2000s (Winberg, 2010), customary forest management practices (Stellmacher, 2007; Tadesse, Zavaleta, Shennan, 2014a).

Our results show that forest loss rates were higher where participatory conservation programs are not active in Yeki. These agree with other findings on the positive roles of PFM programs in forest conservation in southwestern Ethiopia (Gobeze, Bekele, Lemenih, \& Kassa, 2009) and in Bale Mountains of Ethiopia (Yemiru, Roos, Campbell, \& Bohlin, 2010). Such success stories are also consistent with evidences from other regions where increased local access and participation in forest use and management benefits conservation (Barsimantov \& Kendall, 2012; Lakuma, 2000; Scherr, White, \& Kaimowitz, 2002).

Although local people in southwest Ethiopia recognized the importance of PFM, they also described the following challenges: reduction of forest incomes few years after the PFM were established; financial incentives that could not last long; unequal participation of all community members; and lack of transparency regarding the collective benefits from forest use and conservation. PFM is also criticized for its failure to address deforestation and rural poverty in Africa (Polasky, 2003).

\section{Demographic and livelihood factors}

A salient socio-cultural difference between the two districts emerged in the contrasting relationship between population density and forest loss rates, with forests actually better conserved in highly populated areas such as Decha, where traditional forestbased livelihoods (e.g. forest apiculture, and the collection of forest spices and wild coffee) are dominant and forests are less well conserved in highly populated areas such as in Yeki where cereal agriculture and coffee agroforestry prevail.

We argue that this high forest dependency (forest-based livelihoods) (see Byron \& Michael, 1999) might generally have contributed to a relatively non-destructive interaction between forests and people in the region as has been reported by our local informants and researchers on other regions of the world (Arnold \& Ruiz-Perez 2001; Bermeo, Couturier, \& Pizaña, 2014; Gadgil, Berkes, \& Folke, 1993; Sunderlin et al., 2005). Although forest cover can rarely be maintained regardless of population growth such as due to adoption of agroforestry systems in other regions, promoting forest-based ecosystem services and environmental incentive programs can potentially prevent deforestation and forest degradation (Arnold \& Ruiz-Perez 2001; Barsimantov \& Kendall, 2012; Gadgil et al., 1993; Sunderlin et al., 2005; Winberg, 2010; ).

\section{Conclusion}

In southwestern Ethiopia, high deforestation occurred with local deforestation rates that varied through time and correlated with major changes in land-tenure and agricultural development policies that occurred at national scales. We found that forest cover loss occurred with varied deforestation rates between the two districts, reflected in their livelihood practices and conservation approaches. In addition to the spatial differences in deforestation rates between the two districts, the reports from informants suggested that there were distinct patterns of deforestation through time with accelerations and decelerations in forest loss rates. These correlations underpin that deforestation in the region is an outcome of complex interactions between policy-induced and land-tenure changes, agricultural development schemes and resettlement policies in combination with local socio-economic and cultural practices. We observed that rapid deforestation occurred in areas where customary forest use and management regimes have been disrupted, large-scale 
resettlement and associated agricultural expansion have occurred, and local participation in conservation has been low. These imply that forest conservation in the study region can likely be enhanced by (a) intervening in the underlying socioeconomic and land-use policy drivers that have been affecting local deforestation patterns, (b) restoring customary forest ownership and management regimes and increasing local participation in conservation, (c) promoting forest-based ecosystem services and environmental incentive programs that prevent deforestation and forest degradation.

\section{Acknowledgementss}

We thank the members of the Zavaleta lab and three anonymous reviewers for thoroughly reviewing the manuscript, the USGS for providing access for LANDSAT data, the Center for Integrated Spatial Research (UCSC) for providing technical support, and the Christensen Fund (U.S.) (Grant \# 2010-5908018) and the International Foundation for Science (Sweden) (Grant \# D/4834-1) for funding this research.

\section{References}

Arnold, J. E. M., \& Ruiz-Pérez, M. (2001). Can non-timber forest products match tropical forest conservation and development objectives? Ecological Economics, 39, 437-447.

Assefa, E., \& Bork, H. (2014). Deforestation and forest management in southern Ethiopia, investigations in the Chencha and Arbaminch areas. Environmental Management, 53, 284-299.

Barsimantov, J., \& Kendall, J. (2012). Community forestry, common property, and deforestation in Eight Mexican States. Journal of Environment \& Development, 21, 414-437.

Bekele, M. (2003). Forest property rights, the role of the state, and institutional exigency, the Ethiopian experience (Doctoral thesis). Uppsala, Sweden: Swedish University of Agricultural Sciences, Department of Rural Development Studies.

Bermeo, A., Couturier, S., \& Pizaña, M. G. (2014). Conservation of traditional smallholder cultivation systems in indigenous territories: mapping land availability for milpa cultivation in the Huasteca Poblana, Mexico. Applied Geography, 53, 299-310.

Bewket, W. (2002). Land-cover dynamics since the 1950s in Chemoga watershed, Blue Nile basin, Ethiopia. Mountain Research and Development, 22, 263-269.

Bishaw, B. (2001). Deforestation and land degradation in the Ethiopian Highlands, a strategy for physical recovery. Northeast African Studies, 5, 7-26.

Brink, A. B., \& Eva, H. D. (2009). Monitoring 25 years of land cover change dynamics in Africa: a sample based remote sensing approach. Applied Geography, 29, $501-512$.

Byron, N., \& Michael, A. (1999). What futures for the people of the tropical forests. World Development, 27, 789-805.

Center for International Earth Science Information Network (CIESIN)/Columbia University. (2012). National aggregates of geospatial data collection, population, landscape, and climate estimates, version 2 (PLACE II). http//sedac.ciesin. columbia.edu/. Retrieved 15 December 2012.

Central Statistic Authority, CSA. (2012). Population census data. http//www.csa.gov. et. Retrieved 11 December 2012.

Clay, J. W., \& Holcomb, B. K. (1985). Politics and the Ethiopian famine, 1984-1985 cultural Survival report 20, Cambridge, $250 \mathrm{pp}$.

Congalton, R. G. (1991). A review of assessing the accuracy of classifications of remotely sensed data. Remote Sensing of Environment, 37, 35-46.

Crummey, D. (2009). Exploring landscape change in Ethiopia, evidence from imaging and its interpretation. In S. Ege, H. Aspen, B. Teferra, \& S. Bekele (Eds.), Proceedings of the 16th International Conference of Ethiopian Studies ( $\mathrm{pp}$. 173-184). Trondheim, Norway.

Crummey, D. (1998). Deforestation in Wällo, process or illusion? Journal of Ethiopian Studies, $31,1-42$.

CSA. (2011). Agricultural sample survey for 2010/11. Area and production of major Crops. Statistical Bulletin 152. Addis Ababa: Central Statistical Agency of Ethiopia.

Dessie, G., \& Kleman, J. (2007). Pattern and magnitude of deforestation in the south Central rift Valley region of Ethiopia. Mountain Research and Development, 27, $162-168$.

EFAP. (1994). Ethiopian Forestry Action Program. In The challenge for development (Vol. 2). Addis Ababa, Ethiopia: Ministry of Natural Resources Development and Environmental Protection.

Elliott, J. A., Burnside, N. G., Broomhead, T., Kinsey, B. H., \& Kwesha, D. (2006). The nature and extent of landscape change under land resettlement programmes in Zimbabwe. Land Degradation \& Development, 17, 495-508.

Ethiopian National Meteorological Services Agency. (2010). Unpublished Climate Data for Yeki and Bonga stations from 1970-2008. Addis Ababa, Ethiopia.
FAO. (2009). State of the world's forests 2009. Rome. www.fao.org/docrep/011/ i0350e/i0350e00.htm. Retrieved 3 March 2014.

Friis, I. (1992). Forests and forest trees of northeast tropical Africa, their natural habitats and distribution patterns in Ethiopia, Djibouti and Somalia. Royal Botanic Gardens, Kew. London. 396 pp.

Gadgil, M., Berkes, F., \& Folke, C. (1993). Indigenous knowledge for biodiversity conservation. Ambio, 22, 151-156.

Garedew, E., Sandewall, M., Soderberg, U., \& Campbell, B. M. (2009). Land-use and land-cover dynamics in the Central rift Valley of Ethiopia. Environmental Management, 44, 683-694.

Gbetnkom, D. (2005). Deforestation in Cameroon, immediate causes and consequences. Environment and Development Economics, 10, 557-572.

Gebreselassie, S. (2006). Intensification of smallholder agriculture in Ethiopia, options and scenarios. Future agricultures. Sussex, UK: Institute of Development Studies.

Getahun, K., Rompaeya, A. V., Turnhouta, P. V., \& Poesen, J. (2013). Factors controlling patterns of deforestation in moist evergreen forests of southwest Ethiopia. Forest Ecology and Management, 304, 171-181.

Geist, H. J., \& Lambin, E. F. (2002). Proximate causes and underlying driving forces of tropical deforestation. BioScience, 52, 143-150.

Gobeze, T., Bekele, M., Lemenih, M., \& Kassa, H. (2009). Participatory forest management and its impacts on livelihoods and forest status, the case of Bonga forest in Ethiopia. International Forestry Review, 11, 346-357.

Gole, T. W. (2003). Vegetation of the Yayu Forest in southwest Ethiopia, impacts of human use and implications for in-situ conservation of Coffea arabica L. populations (Ph.D. thesis). Gottingen, Germany: University of Gottingen.

Hall, J., Burgess, N. D., Lovett, J., Mbilinyi, B., \& Gereau, R. E. (2009). Conservation implications of deforestation across an elevational gradient in the Eastern Arc Mountains, Tanzania. Biological Conservation, 142, 2510-2521.

Hansen, M. C., Potapov, P. V., Moore, R., Hancher, M., Turubanova, S. A. Tyukavina, A., et al. (2013). High-resolution global maps of 21st-Century Forest cover change. Science, 342, 850-853. http://dx.doi.org/10.1126/science.124 4693.

Hylander, H., Nemomissa, S., Delrue, J., \& Enkossa, W. (2013). Effects of coffee management on deforestation rates and forest integrity. Conservation Biology, 27, 1031-1040.

Kidane, Y., Stahlmann, R., \& Beierkuhnlein, C. (2012). Vegetation dynamics, and land-use and land-cover change in the Bale Mountains, Ethiopia. Environmental Monitoring and Assessment, 184, 7473-7489.

Lakuma, B. M. K. (2000). Participatory forest management, a strategy for sustainable forest management in Africa. community forestry project, Zambia. In Proceedings of the International Workshop on Community Forestry in Africa (pp. 167-174).

Lambin, E. F., Geist, H. J., \& Lepers, E. (2003). Dynamics of land-use and land-cover change in tropical regions. Annual Review of Environment and Resources, 28, 205-241.

Laurance, W. F., \& Balmford, A. (2013). Land use: a global map for road building, comment in Nature. Nature, 495, 308-309.

Laurance, W. F., Cochrane, M. A., Bergen, S., Fearnside, P. M., Delamônica, P., Barber, C. et al. (2001). The future of the Brazilian Amazon. Science, 291, 438-439.

Melaku, B. (2003). Forest property rights, the role of the state, and institutional exigency (Doctoral dissertation). Upssala: Swedish University of Agricultural Sciences.

Mertens, B., Sunderlin, W. D., Ndoye, O., \& Lambin, E. F. (2000). Impact of macroeconomic change on deforestation in South Cameroon, integration of household survey and remotely sensed data. World Development, 28, 983-999.

Meire, E., Frankl, A., De Wulf, A., Haile, M., Deckers, J., \& Nyssen, J. (2013). Land use and cover dynamics in Africa since the nineteenth century, warped terrestrial photographs of North Ethiopia. Regional Environmental Change, 113, 717-737.

Millennium Ecosystem Assessment (MA). (2005). Biodiversity regulation of ecosystem services, current state and trends. Ecosystems and human well-being (pp. 297-329). Island Press.

Ministry of Agriculture and Rural Development, MoARD. (2012). Ethiopia's agricultural sector policy and investment framework, 2010-2020. http//www.moa.gov. et/. Retrieved 10 May 2013.

Pankhurst, R. (1995). The history of deforestation and afforestation in Ethiopia prior to World War I. Northeast African Studies, 2, 119-133.

Peres, C. A., \& Schneider, M. (2012). Subsidized agricultural resettlements as drivers of tropical deforestation. Biological Conservation, 151, 65-68.

Place, F., \& Otsuka, K. (2001). Population, tenure, and natural resource management, the case of customary land area in Malawi. Journal of Environmental Economics and Management, 41, 13-32.

Polasky, C. (2003). Participatory forest management in Africa, lessons not learned. International Journal of Sustainable Development \& World Ecology, 10, 109-118.

Puyravaud, J. P. (2003). Standardizing the calculation of the annual rates of deforestation. Forest Ecology and Management, 177, 593-596.

Rahmato, D. (1994). Land policy in Ethiopia at crossroads. In Proceedings of the Second Workshop of the Land-tenure Project, Working Papers on Ethiopian Development 8, Centre for Environment and Development (SMU), University of Tronheim, Trondheim (pp. 1-20).

Rahmato, D. (2003). Resettlement in Ethiopia, the tragedy of population relocation in 1980 s (2nd ed.). Addis Ababa: Ethiopia, Forum for Social Studies.

Rahmato, D. (2009). The peasant and the state, studies in Agrarian change in Ethiopia 1950s-2000s. Addis Ababa, Ethiopia: Addis Ababa University Press.

Reid, R. S., Kruska, R. L., Muthui, N., Taye, A., Wotton, S., Wilson, C. J., et al. (2000) Land-use and land-cover dynamics in response to changes in climatic 
biological and socio-political forces, the case of south-western Ethiopia. Landscape Ecology, 15, 339-355.

Reusing, M. (2000). Change detection of natural high forests in Ethiopia using remote sensing and GIS techniques. International Archives of Photogrammetry and Remote Sensing, Amsterdam.

Rudel, T. K. (2013). The national determinants of deforestation in sub-Saharan Africa. Philosophical Transactions of the Royal Society of Biological Sciences, 368. http://dx.doi.org/10.1098/rstb.2012.0405, 20120405.

Scherr, S. J., White, A., \& Kaimowitz, D. (2002). Making markets work for forest communities. Washington, D.C: Forest Trends.

Schmitt-Harsh, M. (2013). Landscape change in Guatemala: driving forces of forest and coffee agroforest expansion and contraction from 1990 to 2010. Applied Geography, 40, 40-50.

Senbeta, F., \& Denich, M. (2006). Effects of wild coffee management on species diversity in the Afromontane rainforests of Ethiopia. Forest Ecology and Management, 232, 68-74.

Stauder, J. (1971). The Majangir, ecology and society of a southwest Ethiopian people London: Cambridge University Press.

Stellmacher, T. (2007). Governing the Ethiopian coffee forests, a local level institutional analysis in Kaffa and Bale mountains (Ph.D. dissertation). Bonn, Germany: University of Bonn.

Sunderlin, W. D., Angelsen, A., Belcher, B., Burgers, P., Nasi, R., Santoso, L., et al. (2005). Livelihoods, forests, and conservation in developing countries, an overview. World Development, 33, 1383-1402.

Sunderlin, W. D., Ndoye, O., Bikie, H., Laporte, N., Mertens, B., \& Pokam, J. (2000) Economic crisis, small scale agriculture and forest cover change in Southern Cameroon. Environmental Conservation, 27, 284-290.

Tadesse, G., Zavaleta, E., \& Shennan, C. (2014a). Coffee landscapes as refugia for native woody biodiversity as forest loss continues in southwest Ethiopia. Biological Conservation, 169, 384-391.

Tadesse, G., Zavaleta, E., \& Shennan, C. (2014b). Effects of land-use changes on woody species distribution and above-ground carbon storage of forest-coffee systems. Agriculture. Ecosystems and Environment, 197, 21-30.

Tadesse, G. Zavaleta, E., Shennan, C., \& FitzSimmons, M. (2014c). Prospects for forest-based ecosystem services in forest-coffee mosaics as forest loss continues in southwestern Ethiopia. Applied Geography, 50, 144-151.
TCPE. (2010). Tepi Coffee Plantation Enterprise. Unpublished data. Tepi, southwest Ethiopia.

Teka, B. K., Rompaey, A. V., Poesen, J., Simon, V. B., Deckers, J., \& Amare, K. (2014). Spatial analysis of land-cover changes in Eastern Tigray (Ethiopia) from 1965 to 2007, are there signs of a forest transition? Land Degradation \& Development. http://dx.doi.org/10.1002/ldr.2275.

Tekle, K., \& Hedlund, L. (2000). Land-cover changes between 1958 and 1986 in Kalu District, Southern wello, Ethiopia. Mountain Research and Development, 20, 42-51.

Trombulak, S. C., \& Frissell, C. A. (2000). Review of ecological effects of roads on terrestrial and aquatic communities. Conservation Biology, 14, 18-30.

Vaughan, S. (2003). Ethnicity and power in Ethiopia (PhD dissertation). Edinburgh, UK: University of Edinburgh.

Wiersum, K. F. (2010). Forest dynamics in southwest Ethiopia-Interfaces between ecological degradation and resource enrichment. In F. Bongers, \& T. Tennigkeit (Eds.), Degraded Forests in Eastern Africa-Management and Restoration (pp. 323-342). New York: Earthscan.

Winberg, E. (2010). Participatory forest management in Ethiopia, practices and experiences. Food and agriculture organization sub regional office for Eastern Africa (p. 41). Addis Ababa.

Woien, H. (1995). Deforestation, information and citations, a comment on environmental degradation in Highland Ethiopia. Geojournal, 37, 501-511.

Wood, A. P. (1993). Natural resource conflicts in south-west Ethiopia, state, communities, and the role of the national conservation strategy in the search for sustainable development. Nordic Journal of African Studies, 2, 83-99.

Woube, M. (2005). Effects of resettlement schemes on biophysical and human environments. The case of Gambella region, Ethiopia. Florida: Universal Publishers.

Yemiru, T., Roos, A., Campbell, B. M., \& Bohlin, F. (2010). Forest incomes and poverty alleviation under participatory forest management in the Bale Highlands, Southern Ethiopia. International Forestry Review, 12, 66-77.

Yosinda, S. (2009). Why did the manjo convert to protestant? Social discrimination and coexistence in Kafa, Southwest Ethiopia. In S. Ege, H. Aspen, B. Teferra, \& S. Bekele (Eds.), Proceedings of the 16th International Conference of Ethiopian Studies. Trondheim.

Zeleke, G. \& Hurni, H. (2001). Implications of land-use and land-cover dynamics for mountain resource degradation in the Northwestern Ethiopian highlands. Mountain Research and Development, 21, 184-191. 